\title{
Decolourization of Sugar Beet Molasses Vinasse by Lactic Acid Bacteria - the Effect of Yeast Extract Dosage
}

\author{
Marta Wilk*, Małgorzata Krzywonos, Daniel Borowiak, Przemysław Seruga \\ Department of Bioprocess Engineering, Wrocław University of Economics, Wrocław, Poland
}

Received: 12 December 2017

Accepted: 28 January 2018

\begin{abstract}
Vinasse is the waste product from the production of ethanol that is most loaded with pollutants. Known methods of treating vinasse allow for a reduction in the pollution load, but do not remove the brown colour. The aim of this study was to investigate the effect of the addition of yeast extract (YE) on the decolourization of sugar beet molasses vinasse by lactic acid bacteria (Lactobacillus plantarum, L. casei, and Pediococcus parvulus). Experiments were performed in batch mode in a BioStat B bioreactor (working volume of $2 \mathrm{dm}^{3}$ ) for $72 \mathrm{~h}$ at $35.8^{\circ} \mathrm{C}$ and $\mathrm{pH}_{0}$ of 6.5 . The medium consisted of $25 \% \mathrm{v} / \mathrm{v}$ vinasse, glucose $\left(38.67 \mathrm{~g} \mathrm{dm}^{-3}\right)$, and different amounts of yeast extract addition $\left(2.24,4.48\right.$, and $\left.8.96 \mathrm{~g} \mathrm{dm}^{-3}\right)$. It was observed that an increase in the YE dose in the medium was followed by a decrease in decolourization of the vinasse. The maximum decolourization was $28.36 \%$ ( $\mathrm{YE}=2.24 \mathrm{~g} \mathrm{dm}^{-3}$ ). Regardless of the YE amount added to the medium, removal of invert alkaline degradation products content in all experiments was at a similar level (approx. 13\%). With an increased dose of YE, an increase in the caramel content was observed. The biggest melanoidins removal (62.3\%) was found in the process with the highest YE dose. The acrylamide, 4-methylimidazole, furfural, 5-hydroxymethylfurfural, and 2-acetyl-4-(1,2,3,4)tetrahydroxy-butylimidazole were completely assimilated.
\end{abstract}

Keywords: vinasse, decolourization, lactic acid bacteria, toxic compounds

\section{Introduction}

An increased scientific interest in the colourants from vinasse began in the last decade of the $20^{\text {th }}$ century, when it was shown that some of them are toxic to animals and plants. The source of colourants in beet vinasse is not beet juice, which is colourless, but the process of obtaining white sugar from beet juice and the technology for producing ethanol from molasses.

*e-mail: marta.wilk@ue.wroc.pl
Dominant coloured compounds in sugar beet molasses vinasse (BMV) are formed in the processes of the degradation of sugars, particularly glucose and fructose. These monosaccharides are the result of the inversion of sucrose, which already occurs in the early stages of the production of beet sugar [1]. Under conditions of high temperature and acidic or alkaline $\mathrm{pH}$, they are degraded to highly reactive intermediates, which, by condensation and polymerization, form coloured polymers. These compounds are formed without enzymes. The non-enzymatic reactions of the hexoses may produce melanoidins, invert alkaline degradation 
products (HADP), and caramels. The Maillard reaction occurs in the presence of amine compounds (contained in beet juice) and monosaccharides or carbonyl compounds developing from them; as a result brown products are created. The mechanism of these reactions is very complex and comprises a plurality of successive and parallel chemical reactions. During transformations, inter alia, furfural, 5-hydroxymethylfurfural (5-HMF), and acrylamide are formed. Both 5-HMF and acrylamide are considered as potential carcinogens for humans or can be metabolized to carcinogenic substances [2-3].

During the heating of the sugar with ammonium compounds, i.e., amino acids or ammonia, a series of heterocyclic compounds are formed, including derivatives of imidazoles. This group includes, among others, 2- and 4-methylimidazole (2-MeI, 4-MeI), and 2-acetyl-4-(1,2,3,4)-tetrahydroxy-butylimidazole (THI), for which the toxicological profile has been examined in recent years. A carcinogenic effect has been demonstrated in experiments on rodents for both 2-MeI and 4-MeI [4-5], and the International Agency for Research on Cancer has identified these compounds as probably being carcinogenic to humans [6-7]. Due to the identification of THI only in one of the caramel groups (E 150c), the European Food Safety Authority recommends consuming a 3-times lower daily dose, $100 \mathrm{mg} \mathrm{kg}^{-1}$ body weight, than other caramels. THI is considered to be immunotoxic [8]. In European Union legislation there are detailed regulations on the permissible doses of the caramel components. For a group of caramel, E $150 \mathrm{c}$ is determined a maximum dose of 4-MeI, not more than $250 \mathrm{mg} \mathrm{kg}^{-1}$ and THI, which can be in caramels no more than $10 \mathrm{mg} \mathrm{kg}^{-1}$. The same dose of 4-MeI was established for the caramel E 150d group.

The type, quantity, and characteristics of toxic coloured compounds of vinasse result in the potential utilization of this by-product, especially as a feed additive or fertilizer for growing plants, being highly limited. The coloured compounds may inhibit seed germination and reduce the period of vegetation by lowering the alkalinity of the soil and the availability of manganese [9].

On the other hand, the content of minerals in the vinasse means that it is used by farmers as a fertilizer for certain crops. This applies especially to cane vinasse. This method of vinasse utilization limits the use to nonfood crops due to the uptake of potassium from vinasse by plants. In addition, due to high transportation costs, it is possible to spread vinasse only on fields located relatively close to the distillery. The solution could be to use it for feeding animals. Unfortunately, this method of vinasse development depends on the physiological capabilities of animals.

The significant limitations of applying the above methods of vinasse utilization and the undesirable properties of the coloured components of the vinasse have led scientists to develop decolourization methods for this waste [10]. The removal of colourants by chemical adsorption or by using the active carbon, flocculation, coagulation, and photocatalyst methods have been proposed [10]. These processes, however, have disadvantages, i.e., high operating costs, high consumption of chemicals, fluctuations in the efficiency of colour removal, and a large amount of solid waste after production [10]. Vinasse decolourization by microbiological methods using bacteria, yeast, and fungi are also performed. Of particular interest seems to be the use of a lactic acid bacteria (LAB), which are the natural vinasse microflora. Therefore, the aim of this study was the investigation of yeast extract dose effect on sugar beet molasses vinasse decolourization. In the experiments we research the LAB ability in removing coloured as well as toxic compounds from vinasse.

\section{Materials and Methods}

\section{Materials}

\section{Distillery Wastewater}

The study used the sugar beet molasses vinasse BMV, which was collected from the CHECO Manufacturing Plant, Ltd., Włocławek, Poland. The wastewater was stored in tightly closed containers at $-20^{\circ} \mathrm{C}$. Chemical oxygen demand (COD), biochemical oxygen demand (BOD), and total organic carbon (TOC) of BMV was $\left[\mathrm{g} \mathrm{dm}^{-3}\right]: 89.5,261.7$, and 35.5 , respectively. The $\mathrm{pH}$ and density was $4.8-5.2$ and $21.25 \pm 0.75^{\circ} \mathrm{Blg}$, respectively. The wastewater absorbance measered at $475 \mathrm{~nm}$ was 10.48. The liquid phase consisted of $\left[\mathrm{g} \mathrm{dm}^{-3}\right]$ : invert alkaline degradation products, 20.07 \pm 1 ; caramels, $1.75 \pm 0.09$, melanoidins, $2.91 \pm 0.15$; acrylamide, $0.011 \pm 0.001$; 4-methylimidazole, $0.602 \pm 0.031$; 2-acetyl4-(1,2,3,4)-tetrahydroxy-butylimidazole, $\quad 0.062 \pm 0.003$; furfural, $\quad 0.083 \pm 0.004 ; \quad 5$-HMF, $\quad 0.016 \pm 0.001 ;$ total nitrogen, 5.075 \pm 0.205 ; ammonia nitrogen, $0.217 \pm 0.077$; total phosphorus, $0.1 \pm 0.02$; phosphate phosphorus, $0.06 \pm 0.01$; glycerol, 3.9 \pm 0.19 ; glucose, $1.42 \pm 0.07$; lactic acid, 20.4 \pm 1.02 ; acetic acid, 2.22 \pm 0.11 ; pyroglutamic acid, $8.51 \pm 0.43$; succinic acid, $11.65 \pm 0.58$; isobutyric acid, $21.07 \pm 1.05$; and tartaric acid, $1.04 \pm 0.05$.

\section{Microorganisms and Inoculum}

Lactobacillus plantarum MiLAB393 and Pediococcus parvulus MiLAB099 were obtained from the Department of Microbiology of the Swedish Agricultural University of Uppsala. Lactobacillus casei 0848 was obtained from the Department of Food Chemistry of the Polish University of Technology in Łódź. The strains were stored in the MRS medium (de Man, Rogosa and Sharpe; Biocorp, Poland) with $10 \% \mathrm{v} / \mathrm{v}$ glycerol at $-65^{\circ} \mathrm{C}$.

The unfrozen bacterial cell suspension with volume of $0.1 \mathrm{~cm}^{3}$ was activated in $100 \mathrm{~cm}^{3}$ of sterile MRS medium. The culture was incubated at $37^{\circ} \mathrm{C}$ for 72 hours under static conditions. After this time, the 
culture medium was inoculated with $1 \mathrm{~cm}^{3}$ of a bacterial suspension in MRS medium, which corresponded to $1.5 \mathrm{~g} \mathrm{dm}^{-3}$ of bacteria dry weight.

\section{Process Condition}

The process was carried out in a $5 \mathrm{dm}^{3}$ working volume stirred-tank bioreactor (Biostat_B, B. Braun Biotech International) with a stirrer speed of $200 \mathrm{rpm}$, no aeration, at $30^{\circ} \mathrm{C}$ for 72 hours. The medium consisted of sugar beet molasses vinasse $(25 \% \mathrm{v} / \mathrm{v})$, glucose $\left(38.67 \mathrm{~g} \mathrm{dm}^{-3}\right)$, and yeast extract $(2.24,4.48$, or $8.96 \mathrm{~g} \mathrm{dm}^{-3}$ ). Initial $\mathrm{pH}$ was adjusted to 6.5 with $33 \%$ $\mathrm{NaOH}$. Glucose was added separately, using a membrane filter with a pore diameter of $0.45 \mu \mathrm{m}$ after medium sterilization $\left(121^{\circ} \mathrm{C}, 15 \mathrm{~min}\right)$.

\section{Methods}

The samples were centrifuged at 8,000 $g$ (Sigma $4 \mathrm{~K} 15)$ for $15 \mathrm{~min}$. The decolourization effectiveness was evaluated spectrophotometrically at $475 \mathrm{~nm}$ [11] and it was calculated from the formula:

$$
\% A=\frac{A_{0}-A_{t}}{A_{0}} \cdot 100 \%
$$

...where $A_{0}$ is the initial value of the absorbance and $A_{t}$ is the value of the absorbance in time t.

Bacterial growth was monitored spectrophotometrically at $620 \mathrm{~nm}$. Melanoidins, caramels, and HADP content were determined using the IvanovSapronov method (details were provided in [12]). Melanoidins Glu-Gly concentration were also measured. Standards have been prepared by diluting glucose (4.5 g), glycine (1.88 g), and $\mathrm{NaHCO}_{3}(0.42 \mathrm{~g})$ in $100 \mathrm{dm}^{3}$ distilled water and heating for 7 hours at $95^{\circ} \mathrm{C}$. Water was added during the process. Concentrations of melanoidins Glu-Gly were measured by HPLC (Knauer, UV-VIS detector; column type, Agela Unisol C18, $5 \mu \mathrm{m}$; column size, $4.6 \mathrm{~mm}$ i.d. $\times 250 \mathrm{~mm}$; effluent, $10 \%$ $\mathrm{ACN} / 90 \% \mathrm{H}_{2} \mathrm{O}$; flow rate, $0.5 \mathrm{~cm}^{3} \mathrm{~min}^{-1}$; temperature, $27^{\circ} \mathrm{C}$; wavelength, $290 \mathrm{~nm}$ ) according to the method described by Seruga and Krzywonos [13]. Changes in the content of coloured substances (Glu-Gly melanoidins) were evaluated by the degree of surface area reduction, limited by the chromatogram curve, and calculated for the retention time RT from 3.8 to $6.2 \mathrm{~min}$ for the peak with $\mathrm{RT}=4.8 \mathrm{~min} \pm 0.24 \mathrm{~min}$. Acrylamide (Sigma, Poland) concentration was measured according to the 8316 HPLC method [14]. In experiments, HPLC Knauer was used (UV-VIS detector; column type, Agela Unisol C18, $5 \mu \mathrm{m}$; column size, $4.6 \mathrm{~mm}$ i.d. $\times 250 \mathrm{~mm}$; effluent, distilled $\mathrm{H}_{2} \mathrm{O}$; flow rate, $0.5 \mathrm{~cm}^{3} \mathrm{~min}^{-1}$; temperature, $19^{\circ} \mathrm{C}$; wavelength, $195 \mathrm{~nm})$. Content of 4-methylimidazole (4-MeI) (Alfa Aesar, Germany) and 2-acetyl-4-(1,2,3,4)tetrahydroxy-butylimidazole (THI) (Sigma, Poland) were measured according to the Ciolino HPLC method (Knauer; UV-VIS detector; column type, Agela Unisol C18, $5 \mu \mathrm{m}$; column size, $4.6 \mathrm{~mm}$ i.d. $\times 250 \mathrm{~mm}$; effluent, $\mathrm{pH}=3$ buffer $\left(50 \mathrm{mM} \mathrm{KH}_{2} \mathrm{PO}_{4}\right.$ and $5 \mathrm{mM}$ sulphone sodium acetate) and methanol at the ratio 85:15; flow rate, $0.5 \mathrm{~cm}^{3} \mathrm{~min}^{-1}$; temperature, $25^{\circ} \mathrm{C}$ ), with wavelengths of 215 and $285 \mathrm{~nm}$, respectively [15]. 5-hydroxymethylfurfural (5-HMF) (Aldrich, Poland) and furfural (Acros Organics, Poland) concentrations were also measured by HPLC (Knauer; UV-VIS and RI detectors; column type, Phenomenex ROA organic acids; column size, $7.8 \mathrm{~mm}$ i.d. $\times 300 \mathrm{~mm}$; effluent, $0.5 \mathrm{M} \mathrm{H}_{2} \mathrm{SO}_{4}$; flow rate, $0.6 \mathrm{~cm}^{3} \mathrm{~min}^{-1}$; temperature, $50^{\circ} \mathrm{C}$; wavelength, $280 \mathrm{~nm}$ ) [16].

COD, TOC, total phosphorus (TP), and phosphate phosphorus $\left(\mathrm{P}-\mathrm{PO}_{4}\right)$ were established spectrophotometrically using Hach-Lange cuvette tests [17]. BOD was determined by the respirometry OxiTop method [18]. Total nitrogen was determined by the Kjeldahl method [18]. Ammonia nitrogen concentration was measured by distillation with water vapour in the Parnas [18]. The concentrations of glucose, glycerol, and organic acids were determined by HPLC (Knauer; UV-VIS and RI detectors; column type, Phenomenex ROA organic acids; column size, $7.8 \mathrm{~mm}$ i.d. $\times 300 \mathrm{~mm}$; effluent, $0.005 \mathrm{M} \mathrm{H}_{2} \mathrm{SO}_{4}$; flow rate, $0.5 \mathrm{~cm}^{3} \mathrm{~min}^{-1}$; temperature, $40^{\circ} \mathrm{C}$; wavelength, $210 \mathrm{~nm}$ ).

\section{Results and Discussion}

The effect of adding to the culture medium of nitrogen sources in different doses on the degree of colourants reduction by lactic acid bacteria was tested, during the decolourization process in 3 variants of the medium with different amounts of additive YE (2.24, $\left.4.48,8.96 \mathrm{~g} \mathrm{dm}^{-3}\right)$. The results are shown in Figure 1.

It has been reported that the supplementation of nitrogen sources enhanced and positively affected the decolourization process [19-20]. Krzywonos et al. [21] have used Bacillus megaterium ATCC 14581 for vinasse decolourization. They concluded that to increase colourant removal efficiency from the diluted vinasse used, the medium should be supplemented with $5 \mathrm{~g} \mathrm{dm}^{-3}$ of yeast extract, peptone, and only $0.5 \mathrm{~g} \mathrm{dm}^{-3}$ of glucose. On the other hand, Illakkiam et al. [22] recognized the same value of peptone and glucose $\left(1 \mathrm{~g} \mathrm{dm}^{-3}\right)$ as optimum in the process of Alizarin red $\mathrm{S}$ dye decolourization by Pseudomonas species. However, in distillery effluent decolourization by microbial consortium (Phanerochaete chrysoporium, Pseudomonas aeruginosa, Aspergillus niger), Pal and Vimala [23] used yeast extract as the only external compound. We observed that with an increasing amount of YE in the medium, a decrease in decolourization occurs. Tiwari et al. [24] tested the colour reduction ability of Pediococcus acidilactici B-25 at different nitrogen sources viz. malt, yeast, and beef extract, peptone, $\mathrm{NaNO}_{3}$, and $\mathrm{NH}_{4}\left(\mathrm{SO}_{4}\right)_{2}$. Yeast extract and peptone were found to be the best nitrogen sources, but the highest decolourization was achieved with peptone. 
In the next step, cited authors investigated peptone concentrations ranging from 1 to $6 \mathrm{~g} \mathrm{dm}^{-3}$. They observed that maximal decolourization was achieved at $1 \mathrm{~g} \mathrm{dm}^{-3}$ of nitrogen source concentration and also noticed that above this amount there is a reduction in decolourization. These phenomena were not confirmed in studies by Tondee and Sirianuntapiboon [25] during the cultivation of Lactobacillus plantarum No. PV711861 on cane vinasse. They found that with increasing the concentration of nitrogen sources, the degree of decolourization also increases, and as the best source of nitrogen the authors recognized yeast extract in the amount of $4 \mathrm{~g} \mathrm{dm}^{-3}$. Contrary to this report [25] are Ravikumar et al. [26], who studied decolourization of $15 \%$ diluted anaerobically treated molasses vinasse by Cladosporium cladosporioides, and Boopathy and Senthilkumar [27], who tested the ability to remove colour from medium containing pigment obtained from cane molasses vinasse by Pseudomonas fluorescence. They have found that nitrogen (peptone) supplementation is necessary but an excess of it leads to inhibition of microorganism growth and decolourization. For Bacillus licheniformis (DQ79010), Bacillus sp. (DQ779011), and Alcaligenes sp. (DQ779012) used for decolourization by Bharagava and Chandra [28], the use of the additive of organic nitrogen source (peptone) in an amount greater than $1 \mathrm{~g} \mathrm{dm}^{-3}$, as in our studies after increasing the dose (more than $2.24 \mathrm{~g} \mathrm{dm}^{-3}$ ), contributed to a reduction in the degree of removal of colour. Yadav and Chandra [20] also reported that doses of more than $1 \mathrm{~g} \mathrm{dm}^{-3}$ of organic nitrogen source showed an inhibitory effect on the decolourization process. Moreover, these authors observed in their study that all inorganic nitrogen sources were inhibitory for colour removal. Tiwari et al. [29] studied decolourization of colour pigment obtained from cane molasses vinasse by Bacillus species. Both $B$. subtilis and $B$. cereus showed the highest decolourization degree in peptone-amended medium, at 1 and $4 \mathrm{~g} \mathrm{dm}^{-3}$, respectively. What was interesting is that further increasing peptone concentration caused a reduction in decolourization. Tiwari et al. [30] drew the same conclusions during decolourization by Candida tropicalis RG-9, with the exception of the optimum peptone concentration, $2 \mathrm{~g} \mathrm{dm}^{-3}$. Santal et al. [31] noticed the difference in the preferences of the nitrogen source

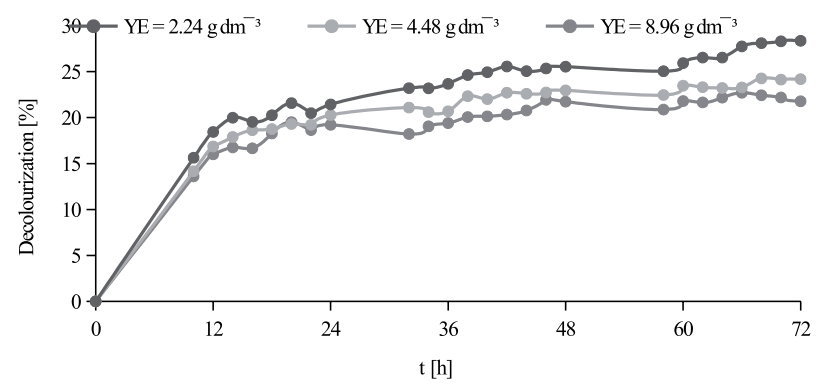

Fig. 1. Effect of yeast extract (YE) dose on decolourization efficiency. during melanoidin removal from cane vinasse by the two strains of Paracoccus. The best result of decolourization by $P$. pantotrophus was obtained by using an inorganic nitrogen source, $\mathrm{NH}_{4} \mathrm{NO}_{3}$, but for the process with species $P$. putida the best was peptone, an organic nitrogen source. Interesting is that Tan et al. [32] used $\left(\mathrm{NH}_{4}\right)_{2} \mathrm{SO}_{4}$ as a nitrogen source during decolourization, whereas they considered yeast extract a vitamin mixture. When they added both compounds, they achieved the best results in azo dye removal by Scheffersomyces spartinae TLHS-SF1. During the cultivation of Coriolus hirsutus, Miyata et al. [33] noted that with the use of $5 \mathrm{~g} \mathrm{dm}^{-3}$ of glucose, the addition of organic nitrogen source (peptone) above $100 \mathrm{mg} \mathrm{N} \mathrm{dm}^{-3}$ resulted in a reduction in the degree of decolourization of synthetic melanoidins. Interestingly, when the cited authors added only $1 \mathrm{~g} \mathrm{dm}^{-3}$ of glucose to the medium, any amount of organic nitrogen source had a negative influence on the process of decolourization. Kumar and Chandra [34] also reported the negative effect of the addition of organic and inorganic nitrogen on the decolourization process. These authors explained the phenomenon as a disorder in the $\mathrm{C} / \mathrm{N}$ ratio and the consequent inhibited activity of peroxidase, which is responsible for the removal of colour. Mohan et al. [35] recognized the addition of both organic and inorganic nitrogen sources as unnecessary, even affecting negatively the process of decolourizing cane vinasse. Naik et al. [36] also did not use a nitrogen source when they determinated bacteria, fungi, and actinomycetes ability to distillery spent wash decolourization. However, in contrast to this study, a nitrogen source was added to the culture medium by Wilk et al. [37] and Limkhuansuwan and Chaiprasert [38] during the decolourization process by lactic acid bacteria, by Ravikumar et al. [39] during colour removal from distillery spent wash by Cladosporium cladosporioides, and by Gupta et al. [40] during the decolourization of molasses melanoidin by Candida sp. Similarly, Sirianuntapiboon et al. [41], who during the cultivation of acetogenic bacteria in a medium containing colour pigment obtained from cane vinasse, noticed the positive effect of the nitrogen source addition, mainly yeast extract and peptone, on the decolourization process. Moreover, the cited authors conducted an experiment in which the medium was complemented with yeast extract in the concentration range of 2 to $10 \mathrm{~g} \mathrm{dm}^{-3}$, and they demonstrated that the YE addition of more than $2 \mathrm{~g} \mathrm{dm}^{-3}$ has no effect on the degree of decolourization. Similar

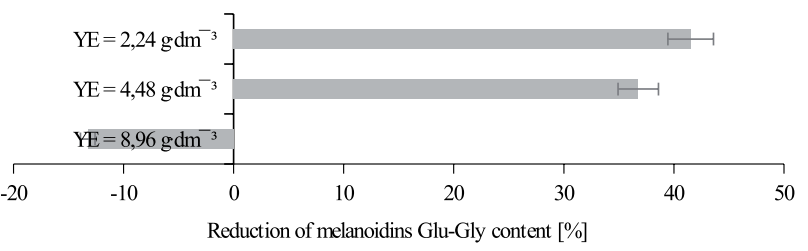

Fig. 2. Reduction of melanoidin glucose-glycine (Glu-Gly) content depending on yeast extract (YE) dose. 
results were obtained by Ohmomo et al. [42] during decolourization using Colorius versicolor PS4a in media containing peptone in concentrations ranging from 0.05 to $0.5 \%$. In the cited studies, the degree of decolourization did not differ by more than $5 \%$. Sirianuntapiboon et al. [43] conducted a decolourization of the medium comprising a vinasse colourant by yeast Citeromyces sp. WR-43-6 using an inorganic nitrogen source. They noted that with increasing nitrogen concentration, the degree of removal of coloured compounds in the tested medium also increased. We recorded a similar relationship between decolourization and YE concentration for reducing the melanoidins Glu-Gly content (Fig. 2). In this case, wherein the YE concentration was the highest in the medium, $8.96 \mathrm{~g} \mathrm{dm}^{-3}$, there was an increase of the colourant concentration. The highest lactic acid bacteria ability to melanoidins Glu-Gly removal, amounting to $41.53 \%$, was noted in the process with $2.24 \mathrm{~g} \mathrm{dm}^{-3}$ YE. Similar observations were made by Krzywonos and Seruga [44], who obtained melanoidins Glu-Gly removal amounting to $42,40,29.3$, and $7.4 \%$ for bacteria $P$. parvulus, $P$. pentosaceus, L. plantarum, and $W$. soli, respectively;

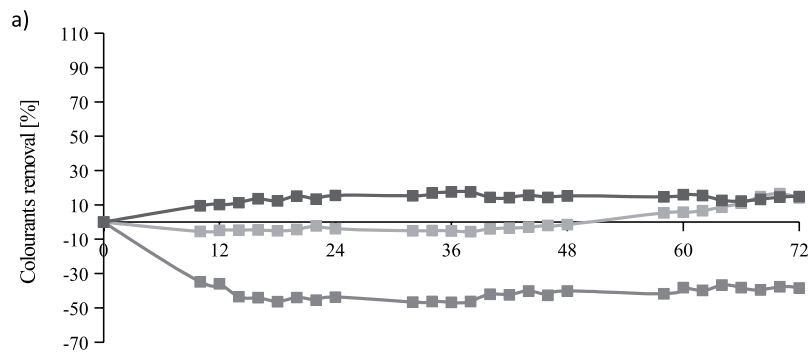

$\mathrm{t}[\mathrm{h}]$

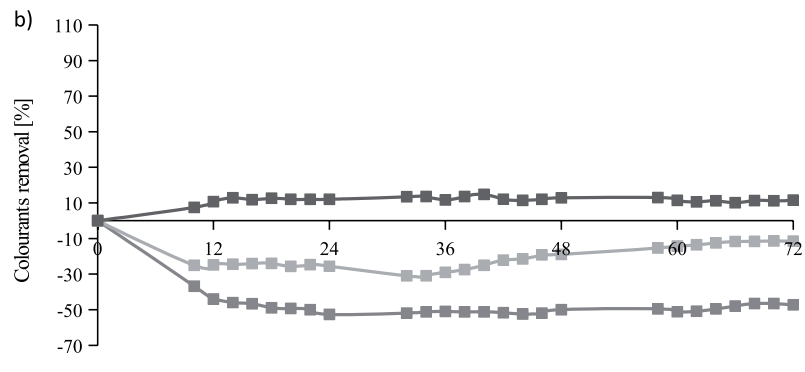

$\mathrm{t}[\mathrm{h}]$

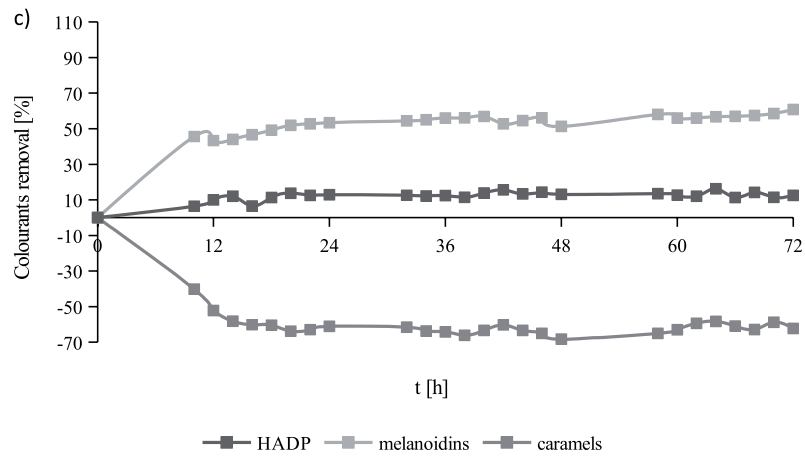

Fig. 3. Invert alkaline degradation products (HADP), melanoidins, and caramel reduction depending on yeast extract (YE) dose $\left[\mathrm{g} \mathrm{dm}^{-3}\right.$ : a) 2.24 b) 4.48 c) 8.96. and Krzywonos et al. [45] for the bacteria P. parvulus $(41 \%)$ in the process of BMV decolourization in shake cultures. Different observations were made by Krzywonos et al. [46], who during the process using L. casei did not note any change in the melanoidins Glu-Gly content. The cited authors [45-46] also observed no change in the number of peaks on chromatograms. A reduction of melanoidins Glu-Gly was also reported by Bharagava et al. [11], who observed the formation of new peaks in the chromatogram. It should be noted, however, that the cited authors [11, 44-46] as a measure of the content of melanoidins marked on the Glu-Gly standard, accepted the area confined to chromatogram curve for a much wider range of retention time. This study was taken as a measure of the melanoidins Glu-Gly surface area (RT for 3.8 to $6.2 \mathrm{~min}$ ) corresponding to the peak with retention time of $4.8 \mathrm{~min}$. According to them, this may indicate the formation of metabolites as a result of biodegradation and biotransformation of melanoidins. Probably the degradation of colourants involves a change in their molecular structure, which is not accompanied by mineralization of organic matter [47].

Regardless of the amount of YE added to the medium, the reduction ratio of HADP content in all experiments was at a similar level of approx. 13\% (Fig. 3).

Along with the increase of the YE amount added to the medium (i.e., 2.24, 4.48, and $8.96 \mathrm{~g} \mathrm{dm}^{-3}$ ), an increase in the concentration of caramels (respectively 38.5, 47.3, and 62.3\%) was observed. This dependency was not reported by Krzywonos et al. [46] in the process of sugar beet vinasse decolourization conducted in shake flasks using bacteria $L$. casei, during which there was an increase in caramels as well as HADP content, and removal of melanoidins was $427 \%$.

In contrast to the results obtained by HPLC (melanoidins Glu-Gly), no relationship was found between the removal of melanoidins and the degree of reduction of the BMV colour. The largest decrease $(62.3 \%)$ of melanoidins was found for the process in which $8.96 \mathrm{~g} \mathrm{dm}^{-3}$ YE was added to the medium. In the case of the lowest dose of the nitrogen source, melanoidin reduction was $14 \%$, and in the experiment with the addition of $4.48 \mathrm{~g} \mathrm{dm}^{-3} \mathrm{YE}$ an increase of these coloured compounds of $11.5 \%$ was obtained.

It was also found that the increase of the initial yeast extract concentration in the medium can contribute to the increase of biomass (Fig. 4). In the process, which was carried out in a medium with the addition of the largest YE dose, at the end of the process, the dry weight of the bacteria was $0.621 \mathrm{~g} \mathrm{dm}^{-3}$.

The concentration of lactic acid after 72 hours of the process was similar in all experiments and amounted to approx. $13 \mathrm{~g} \mathrm{dm}^{-3}$. The decrease in the concentration of total nitrogen in the medium was higher the more YE was added, and was $0.056,0.112$, and $0.616 \mathrm{~g} \mathrm{dm}^{-3}$ (reduction rate equal to $3.45,6.25$, and $26.19 \%$ ) for $\mathrm{YE}$ additive $\left[\mathrm{g} \mathrm{dm}^{-3}\right]: 2.24,4.48,8.96$, respectively. In all of the processes bacteria assimilated a similar amount 


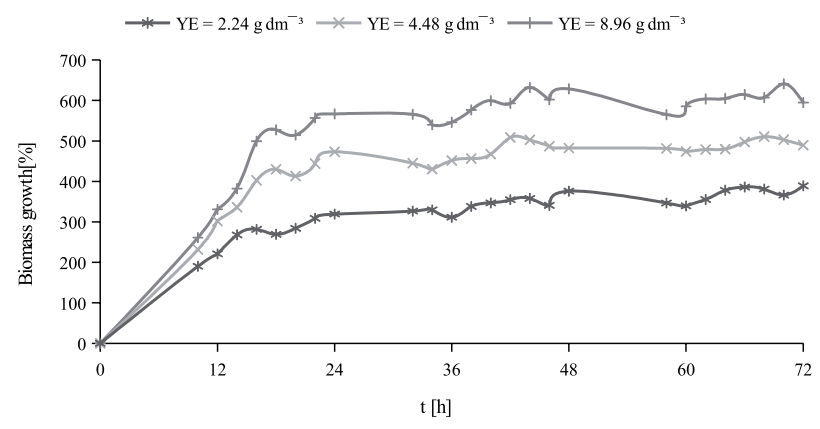

Fig. 4. Bacterial biomass growth in experiments with different yeast extract (YE) doses.

of the total phosphorus, from 0.07 to $0.12 \mathrm{~g} \mathrm{dm}^{-3}$. The glucose removal in all experiments was at similar levels and amounted to $45.11,45.65$, and $52.03 \%$ for $\mathrm{YE}$ addition $2.24,4.48$, and $8.96 \mathrm{~g} \mathrm{dm}^{-3}$, respectively. Probably higher biomass growth in experiments with an increased YE dose in medium may be associated with a greater assimilation of nitrogen by bacteria.

Interestingly, in the experiment with the YE addition, which achieved the highest degree of colour reduction, there was an increase in total organic carbon of $4 \mathrm{~g} \mathrm{dm}^{-3}$, while in the experiment with the lowest decolourization there was a decrease in TOC of $1 \mathrm{~g} \mathrm{dm}^{-3}$. The process in which the YE additive equals $4.48 \mathrm{~g} \mathrm{dm}^{-3}$ was used, there were no major changes in the concentration of TOC. In the experiments carried out in the medium with a YE dose of 2.24 and $4.48 \mathrm{~g} \mathrm{dm}^{-3}$, an increase in COD values of respectively 6.0 and $2.3 \%$ was noted, and in the experiment in which the YE additive was $8.96 \mathrm{~g} \mathrm{dm}^{-3}$, a decrease in the value of this parameter by $3.5 \%$ was observed. These changes were likely to be due to the assimilation of betaine (data not shown) - the dominant amino acid in used vinasse and which is not recognized by the COD test, but which is recognized by the TOC test.

In presented processes with increasing concentrations of $\mathrm{YE}$ added to the medium, a decrease in the degree of THI removal from 100 to $83 \%$ was achieved. Analyzing the acrylamide, 4-MeI, furfural, and 5-HMF contents in the medium after 72 hours of the processes, the presence of these compounds was not observed. According to literature data, furfural and 5-HMF content in the medium may inhibit the growth of LAB and the synthesis of lactic acid [48-49]. According to Feng et al. [48], furfural caused a prolongation of the lag phase of the growth of the bacteria Lactobacillus thermophilus and Lactobacillus bulgarus. Jang et al. [49] found that the presence of 5-HMF and furfural in the medium during the cultivation of Lactobacillus rhamnosus KY-3 reduced the productivity of lactic acid. 5-HMF and furfural in the medium used in the presented study was lower than the additives tested as inhibitors of the cited authors. However, the presence of these compounds in the medium at the end of the processes was not observed.

\section{Conclusions}

Based on the data obtained in these studies, it was seen that increasing the amount of organic nitrogen (from $2.24 \mathrm{~g} \mathrm{dm}^{-3}$ to 4.48 and $8.96 \mathrm{~g} \mathrm{dm}^{-3}$ ) in the medium resulted in higher biomass growth, but did not contribute to the increase of colour removal. On this basis, we can say that an optimal dose of yeast extract for this process is $2.24 \mathrm{~g} \mathrm{dm}^{-3}$. The highest HADP and melanoidins removal were approx. $13 \%$ and $62.3 \%$, respectively. Caramel content was increasing in all of the experiments $(38.46 \%, 47.3 \%$, and $63.27 \%$, respectively, for experiment with yeast extract dosage of 2.24, 4.48, and $\left.8.96\left[\mathrm{~g} \mathrm{dm}^{-3}\right]\right)$. The acrylamide, 4-methylimidazole, furfural, 5-hydroxymethylfurfural, and 2-acetyl-4$(1,2,3,4)$-tetrahydroxy-butylimidazole were completely assimilated.

Future study should be concentrated on continuous processes in a bioreactor, and for explaining how lactic acid bacteria decolorize vinasse. The proposed process can be treated as a pre-treatment of vinasse containing coloured substances, which are not removed during anaerobic processes.

\section{Acknowledgements}

This study was financed by the National Science Centre (Poland) under Project No. N N312 421940.

\section{Conflict of Interest}

The authors declare no conflict of interest.

\section{References}

1. ĆOSOVIĆ B., VOJVODIĆ V., BOŠKOVIĆ N., PLAVŠIĆ M., LEE C. Characterization of natural and synthetic humic substances (melanoidins) by chemical composition and adsorption measurements. Org. Geochem. 41 (2), 200, 2010.

2. COCA M., GARCÍA T., GONZÁlEZ G., PEÑA M., GARCÍA A.J. Study of coloured components formed in sugar beet processing. Food Chem. 86 (3), 421, 2004.

3. POLAK-ŚLIWIŃSKA M., ŁAMEJKO Ł., KUBIAK M.S. Patulin and 5-HMF content in fruit and vegetable juices from ecological and commercial productionBromat. Chem. Toksykol. 46 (1), 80, 2013.

4. NATIONAL INSITUTES OF HEALTH, NTP technical report on the toxicity studies of 2- and 4-Methylimidazole (CAS No. 693-98-1 and 822-36-6) administered in feed to $\mathrm{F} 344 / \mathrm{N}$ rats and $\mathrm{B} 6 \mathrm{C} 3 \mathrm{~F} 1$ mice, Toxicity report series, 2004.

5. NATIONAL INSTITUTES OF HEALTH, NTP technical report on the toxicology and carcinogenesis studies of 4-methylimidazole in F344/N rats and B6C3F1 mice (feed studies), Toxicity report series, 2007.

6. INTERNATIONAL AGENCY FOR RESEARCH ON CANCER. Working group on the evaluation of 
carcinogenic risks to humans 2-Methylimidazole. IARC Monogr. Eval. Carcinog. Risks Hum. 101, 142, 2012.

7. INTERNATIONAL AGENCY FOR RESEARCH ON CANCER. Working group on the evaluation of carcinogenic risks to humans 4-Methylimidazole. IARC Monogr. Eval. Carcinog. Risks Hum. 101, 447, 2012.

8. EUROPEAN FOOD SAFETY AUTHORITY. Refined exposure assessment for caramel colours (E 150a, c, d). EFSA J. 10, 1, 2012

9. AGARWAL S.C., PANDEY S.G. Soil pollution by spent wash discharge: depletion of manganese (II) and impairment of its oxidation. J. Environ. Biol. 15 (1), 49, 1994.

10. CHOWDHARY P., RAJ A., BHARAGAVA R. N. Envirinmental pollution and health hazards from distillery wastewater and treatment approaches to combat the environmental threats: A review. Chemosphere. 2017.

11. BHARAGAVA R.N., CHANDRA R., RAI V. Isolation and characterization of aerobic bacteria capable of the degradation of synthetic and natural melanoidins from distillery effluent. World J. Microbiol. Biotechnol. 25 (5), 737, 2009.

12. KRZYWONOS M., SERUGA P., WILK M., BOROWIAK D., STELMACH K. Separation of colorants in sugar beet vinasse using gel chromatography. Acta Sci. Pol. Biotechnol. 15 (1), 15, 2016.

13. SERUGA P., KRZYWONOS M. Screening of medium components and process parameters for sugar beet molasses vinasse decolorization by Lactobacillus plantarum using Plackett-Burman experimental design. Pol. J. Environ. Stud. 24 (2), 683, 2015.

14. ENVIRONMENTAL PROTECTION AGENCY. Method 8316 (SW-846): Acrylamide, acrylonitrile and acrolein by High Performance Liquid Chromatography (HPLC), 1994.

15. CIOLINO L.A. Determination and classification of added caramel color in adulterated acerola juice formulations. J. Agric. Food Chem. 46 (5), 1746, 1998.

16. SLUITER A., HAMES B., RUIZ R., SCARLATA C., SLUITER J., TEMPLETON D. Determination of sugars, byproducts, and degradation products in liquid fraction process samples. Technical Report NREL/TP-510-42623, National Renewable Energy Laboratory, U.S. Department of Energy, 2008.

17. ANONYMOUS. Handbook of photometrical operation analysis. Dr. Lange BDB 079, 2000 [In German].

18. AMERICAN PUBLIC HEALTH ASSOCIATION. Standard methods for examination of water and wastewater, $22^{\text {nd }}$ edn. APHA, AWWA, WEF, Washington, 2012.

19. SANTAL A.R., SINGH N.P., SAHARAN B.S. Biodegradation and detoxification of melanoidin from distillery effluent using an aerobic bacterial strain $\mathrm{SAG}_{5}$ of Alcaligenes faecalis. J. Hazard. Mater. 193, 319, 2011.

20. YADAV S., CHANDRA R. Biodegradation of organic compounds of molasses melanoidin (MM) from biomethanated distillery spent wash (BMDS) during the decolourization by a potential bacterial consortium. Biodegradation. 23 (4), 609, 2012.

21. KRZYWONOS M., CHAŁUPNIAK A., ZABOCHNICKA-ŚWIĄTEK M. Decolorization of beet molasses vinasse by Bacillus megaterium ATCC 14581. Biorem. J. 21 (2), 81, 2017.

22. ILLAKKIAM D., SUBHA D., AHILAV., GEETHA N. Decolorization of Alizarin red $\mathrm{S}$ dye by bacterial strains isolated from industrial effluents. Int. J. Plant Anim. Environ. Sci. 6 (1), 268, 2016.
23. PAL S., VIMALA Y. Bioremediation and decolorization of distillery effluent by novel microbial consortium. Euro. J. Exp. Bio. 2 (3), 496, 2012.

24. TIWARI S., RAI P., YADAV S.K., GAUR R. A novel thermotolerant Pediococcus acidilactici B-25 strain for color, COD, and BOD reduction of distillery effluent for end use application. Environ. Sci. Pollut. Res. 20 (6), 4046, 2013.

25. TONDEE T., SIRIANUNTAPIBOON S. Decolorization of molasses wastewater by Lactobacillus plantarum No. PV71-1861. Bioresour. Technol. 99 (14), 6258, 2008.

26. RAVIKUMAR R., VASANTHI N.S., SARAVANAN K. Single factorial experimental design for decolorizing anaerobically treated distillery spent wash using Cladosporium cladosporioides. Int. J. Environ. Sci. Tech. 8 (1), 97, 2011.

27. BOOPATHY M.A., SENTHILKUMAR S.N.S. Media optimization for the decolorization of distillery spent wash by biological treatment using Pseudomonas fluorescence. Int. J. Innov. Eng. Technol. 4 (1), 8, 2014.

28. BHARAGAVA R.N., CHANDRA R. Biodegradation of the major color containing compounds in distillery wastewater by an aerobic bacterial culture and characterization of their metabolites. Biodegradation. 21 (5), 703, 2010.

29. TIWARI S., GAUR R., RAI P., TRIPATHI A. Decolorization of distillery effluent by thermotolerant Bacillus subtilis. Am. J. App. Sci. 9 (6), 798, 2012.

30. TIWARI S., GAUR R., SINGH R. Decolorization of a recalcitrant organic compound (Melanoidin) by a novel thermotolerant yeast, Candida tropicalis RG-9. BMC Biotechnol. 12 (30), 1, 2012.

31. SANTAL A.R., SINGH N.P., SAHARAN B.S. A novel application of Paracoccus pantotrophus for the decolorization of melaoidins from distillery effluent under static conditions. J. Environ. Manage. 169, 78, 2016.

32. TAN L., HE M., SONG L., FU X., SHI S. Aerobic decolorization, degradation and detoxification of azo dyes by a newly isolated salt-tolerant yeast Scheffersomyces spartinae TLHS-SF1. Biores. Technol. 203, 287, 2016.

33. MIYATA N., MORI T., IWAHORI K., FUJITA M. Microbial decolorization of melanoidin-containing wastewaters: Combined use of activated sludge and the fungus Coriolus hirsutus. J. Biosci. Bioeng. 89 (2), 145, 2000.

34. KUMAR P., CHANDRA R. Decolourization and detoxification of synthetic molasses melanoidins by individual and mixed cultures of Bacillus spp. Bioresour. Technol. 97 (16), 2096, 2006.

35. MOHANA S., DESAI C., MADAMWAR D. Biodegradation and decolourization of anaerobically treated distillery spent wash by a novel bacterial consortium. Biores. Technol. 98 (2), 333, 2007.

36. NAIK N., JAGADEESH K. S., NOOLVI M. N. Enhanced degradation of melanoidin and caramel in biomethaned distillery spentwash by microorganisms isolated from mangroves. Iranica J. Energ. Environ. 1 (4), 347, 2010.

37. WILK M., KRZYWONOS M., SERUGA P. Microbiological colourants removal from sugar beet molasses vinasse - the effects of process parameters and vinasse dillution. Econ. Environ. Stud. 17 (2), 335, 2017.

38. LIMKHUANSUWAN V., CHAIPRASERT P. Decolorization of molasses melanoidins and palm oil mill effluent phenolic compounds by fermentative lactic acid bacteria. J. Environ. Sci. 22 (8), 1209, 2010.

39. RAVIKUMAR R., VASANTHI N. S., SARAVANAN K. Biodegradation and decolorization of distillery spent 
wash with product release by a novel strain Cladosporium cladosporioides: optimization and biokinetics. Chem. Biochem. Eng. 27 (3), 373, 2013.

40. GUPTA M., MISHRA P. K., KUMAR A., TIWARI S. Decolorization of molasses melanoidin by Candida Sp. Indian J. Appl. Pure Bio. 26 (2), 199, 2011.

41. SIRIANUNTAPIBOON S., PHOTHILANGKA P., OHMOMO S. Decolorization of molasses wastewater by a strain No.BP103 of acetogenic bacteria. Bioresour. Technol. 92 (1), 31, 2004.

42. OHMOMO S., ITOH N., WATANABE Y., KANEKO Y., TOZAWA Y., UEDA K. Decolorization of molasses waste water with mycelia of Coriolus versicolor Ps4a. Agric Biol. Chem. 49 (9), 2551, 1985.

43. SIRIANUNTAPIBOON S., ZOHSALAM P., OHMOMO S. Decolorization of molasses wastewater by Citeromyces sp. WR-43-6. Process. Biochem. 39 (8), 917, 2004.

44. KRZYWONOS M., SERUGA P. Decolorization of sugar beet molasses vinasse, a high-strength distillery wastewater, by lactic acid bacteria. Pol. J. Environ. Stud. 21 (4), 943, 2012.
45. KRZYWONOS M., TRZEPAK K., WILK M. Removal of beet vinasse colorants using Pediococcus parvulus MiLab099: effect of yeast extract and concentration of vinasse. Acta Sci. Pol. Biotechnol. 13 (4), 29, 2014.

46. KRZYWONOS M., KOPACZ M., WILK M. DDecolorization of molasses vinasse with using a strain of lactic acid bacteria Lactobacillus casei 0848. Acta Sci. Pol. Biotechnol. 13 (3), 19, 2014.

47. DWYER J., KAVANAGH L., LANT P. The degradation of dissolved organic nitrogen associated with melanoidin using a UV/H2O2 AOP. Chemosphere. 71 (9), 1745, 2008.

48. FENG Y., QI X., JIAN H., SUN R., JIANG J. Effect of inhibitors on enzymatic hydrolysis and simultaneous saccharification fermentation for lactic acid production from steam explosion pretreated Lespedeza stalks. BioResources. 7 (3), 3755, 2012.

49. JANG S.-S., SHIRAI Y., UCHIDA M., WAKISAKA M. Potential use of Gelidium amansii acid hydrolysate for lactic acid production by Lactobacillus rhamnosus. Food Technol. Biotechnol. 51 (1), 131, 2013. 